\title{
Zinc and Iron Nutrition to Increase the Productivity of Pearl Millet- Mustard Cropping System in Salt Affected Soils
}

\author{
B.L. Meena ${ }^{*}$, P. Kumar, A. Kumar, R.L. Meena, M.J. Kaledhonkar and P.C. Sharma \\ Project Coordinating Unit, ICAR-Central Soil Salinity Research Institute, Karnal, 132 001, \\ Haryana, India \\ *Corresponding author
}

\begin{tabular}{|l|}
\hline Ke y w o r d s \\
$\begin{array}{l}\text { Ferrous iron, Iron, } \\
\text { Zinc, Pear millet, } \\
\text { Mustard, Salt } \\
\text { Affected Soils }\end{array}$ \\
\hline Article Info \\
\hline $\begin{array}{l}\text { Accepted: } \\
\text { 17 July 2018 } \\
\text { Available Online: } \\
\text { 10 August } 2018\end{array}$ \\
\hline
\end{tabular}

\section{A B S T R A C T}

The abiotic stresses, such as soil salinity and sodicity are largely responsible for the low productivity of crops mainly due to low availability of micro-nutrients especially as zinc $(\mathrm{Zn})$ and iron $(\mathrm{Fe})$. Therefore, judicious management of plant nutrients in these soils is as important as their reclamation. A field experiment was conducted for 4 consecutive years, consisting of 12 treatments laid out in randomized block design to evaluate the effect of rate and methods of zinc and iron as single or combined soil as well as foliar application in pearl millet-mustard cropping system grown on salt affected soils. Soil application of $\mathrm{Zn}$ and Fe were applied at the time of sowing with FYM or without FYM (addition of FYM done only in pearl millet) and foliar application of respective nutrients were also applied at 30 and 45 days after sowing of crops. The results of experiment showed that, application of FYM $10 \mathrm{t} \mathrm{ha}^{-1}$ along with $\left.5 \mathrm{~kg} \mathrm{Zn+10} \mathrm{kg} \mathrm{Fe} \mathrm{significantly} \mathrm{(} \mathrm{p}=0.05\right)$ improved the yield parameters of pearl millet and mustard followed by $5 \mathrm{~kg} \mathrm{ha}^{-1} \mathrm{Zn}$ and $10 \mathrm{~kg} \mathrm{ha}^{-1} \mathrm{Fe}$ as soil application. The results also indicated that combined soil application of $5 \mathrm{~kg} \mathrm{Zn+10} \mathrm{kg} \mathrm{Fe}$ $+10 \mathrm{t}$ FYM increased the pearl millet grain yield $\left(36.6 \mathrm{q} \mathrm{ha}^{-1}\right)$ and mustard seed yield $(22.7$ $\mathrm{q} \mathrm{ha}^{-1}$ ) by $57.1 \%$ and $42.8 \%$ higher over control, however, yield improvement was 35.6 and $20.7 \%$ due to application of $5 \mathrm{~kg} \mathrm{Zn+10} \mathrm{kg} \mathrm{Fe} \mathrm{without} \mathrm{FYM,} \mathrm{respectively,} \mathrm{in} \mathrm{pearl}$ millet and mustard over control. Ferrous-iron content in both crops proved to be a better index of Fe nutrition status compared to total plant Fe and DTPA- extractable soil Fe under salt affected soils. Salt affected soils are having vast potential to produce a significant amount of food grain by applying optimum dose of Zn, Fe and FYM in pearl millet and mustard. Combined foliar application of $\mathrm{Zn}$ and Fe also increased the yields of pearl millet and mustard grown in saline soils. Ferrous iron $\left(\mathrm{Fe}^{2+}\right)$ is better indicator for iron nutrition in crops.

\section{Introduction}

Pearlmillet [Pennisetum glaucum (L.) R. Br. Emend Stuntz] - mustard [Brassica juncea (L.) Czernj and Coss.] cropping system is one of the predominant cropping systems in marginal and sub-marginal land including salt affected soils in India under scarcity of good quality water and rainfed conditions. The north-western parts of Indian states are having predominantly saline and alkaline soils with poor fertility. Poor availability of micronutrients mainly zinc $(\mathrm{Zn})$ and iron $(\mathrm{Fe})$ as well as poor agronomic practices further 
reduces the availability of these nutrients to plants which led to reduced growth and yield (Raja et al., 2012; Meena et al., 2014). The various physico-chemical processes also mediated the $\mathrm{Zn}$ and $\mathrm{Fe}$ availability in alkaline soils (Meena et al., 2013), i.e. variation in chemical composition of salt affected soils, precipitation-dissolution reactions, adsorption kinetics, transformations of nutrients, and crop responses to applied nutrients greatly vary (Katyal and Sharma, 1980; Datta et al., 2013). Application of micronutrients decides the yield potential of crops in deficient soil with low carbon content (Shukla et al., 2014; Ray et al., 2014). Use of FYM and other organic manures produce various types of organic acids during the microbial decomposition and converted the plant nutrient from immobile to mobile in the soil solution (Dotaniya et al., 2016). Combined soil application of micronutrients with FYM significantly enhanced the mustard yield in normal soil (Meena et al., 2006). Organic manures not only supply micronutrients but also influence the transformation of native micronutrients in soil, thereby enhancing their availability to crops (Pal et al., 2008; Meena et al., 2018). The contributions of soil organic matter to available pools of micronutrients are limited and thus, prone to deficiency of one or more micronutrients especially $\mathrm{Zn}$ and $\mathrm{Fe}$ in salt affected soils (Sharma et al., 2009). Straight or alone application of zinc and Fe fertilizer in normal soil increased the biological produce in mustard (Singh et al., 2010) and in pearl millet (Shukla et al., 2014). In contrast to $\mathrm{Zn}$ fertilizer, soil application of inorganic Fe salts is ineffective in controlling Fe-deficiency in alkaline soil, except when application rates are as higher as $150 \mathrm{~kg} \mathrm{FeSO} \mathrm{ha}^{-1}$ under aerobic rice (Pal et al., 2008). Also, the efficacy of foliar spray of $\mathrm{Zn}$ and $\mathrm{Fe}$ varies with species and cultivars (Meena et al., 2016). It is well documented that application of $\mathrm{Zn}$ in saline soil increased the its concentration in maize (Rahman et al., 1993) and tomato (Knight et al., 1992) and decreased in case of cucumber leaves (Al- Harbi, 1995). Influences of Fe application in plants were also inconsistent as $\mathrm{Zn}$ concentration in plants (Achakzai et al., 2010). Ferrous iron $\left(\mathrm{Fe}^{2+}\right)$ content in rice and other plants proved to be a better index of $\mathrm{Fe}$ nutrition status compared to total plant $\mathrm{Fe}$ and chemically extractable soil Fe (Katyal and Sharma, 1980; Meena et al., 2016). Limited information is available on the adequate level of $\mathrm{Fe}^{2+}$ in pearl millet and mustard under field conditions which can be used for monitoring purpose.

The available information pertaining to ways and means for optimizing $\mathrm{Zn}$ and $\mathrm{Fe}$ requirements to ameliorate deficiencies of these nutrients in various crops have mostly been confined to normal soil conditions. Such information is yet to be generated for pearl millet and mustard cropping sequence grown under salt affected soils. Therefore, the judicious $\mathrm{Zn}$ and $\mathrm{Fe}$ management of plant nutrients in salt affected soils can enhance the food grain production potential of degraded soils. For this, a hypothesis was formulated to assess the requirement of $\mathrm{Zn}$ and $\mathrm{Fe}$ application with FYM and its effect on pearl millet- mustard cropping system.

\section{Materials and Methods}

\section{Physico-chemical properties of experiment soil}

A field experiment on pearl millet-mustard cropping system was carried out during 20132017 at the experimental farm Nain (29 19'7.09" N latitude and 76 47'30.0' E longitude), district, Panipat of ICAR-Central Soil Salinity Research Institute (CSSRI), Karnal, India. The soil of the experimental site was sandy loam and the climate is semi-arid, sub-tropical with hot summers (May-June) and cold winters (December-January). Initial soil samples were collected $(0-15 \mathrm{~cm}$ depth) 
from the experimental site and physicochemical properties of the experimental soil and FYM are given in Table 1. Soil samples were extracted with $0.005 \mathrm{M}$ DTPA (Lindsay and Norvell, 1978) and Fe in the extract was determined with the help of Flame Atomic Absorption Spectrophotometer (Model-ZEEnit 700). For analysis of total $\mathrm{Zn}$ and $\mathrm{Fe}$ in soil and FYM samples were extracted with aqua regia $\left(\mathrm{HNO}_{3}+3 \mathrm{HCl}\right)$ on a hot plate and metal contents in the digest were determined as per the procedure of Quevauviller (1998) using AAS.

\section{Treatment details}

There were 12 treatments combinations, i.e. $\mathrm{T}_{1}$ - Control, $\mathrm{T}_{2}-5 \mathrm{~kg} \mathrm{Zn} \mathrm{ha}{ }^{-1}, \mathrm{~T}_{3}-6.25 \mathrm{~kg} \mathrm{Zn}$ $\mathrm{ha}^{-1}, \mathrm{~T}_{4^{-}} 7.5 \mathrm{~kg} \mathrm{Zn} \mathrm{ha}^{-1}, \mathrm{~T}_{5^{-}} 7.5 \mathrm{~kg} \mathrm{Fe} \mathrm{ha}^{-1}, \mathrm{~T}_{6^{-}}$ $10 \mathrm{~kg} \mathrm{Fe} \mathrm{ha}{ }^{-1}, \mathrm{~T}_{7^{-}} 12.5 \mathrm{~kg} \mathrm{Fe} \mathrm{ha}^{-1}, \mathrm{~T}_{8^{-}} 5 \mathrm{~kg}$ $\mathrm{Zn}+10 \mathrm{~kg} \mathrm{Fe} \mathrm{ha}{ }^{-1}, \mathrm{~T}_{9^{-}} 5 \mathrm{~kg} \mathrm{Zn}+10 \mathrm{~kg} \mathrm{Fe}+10 \mathrm{t}$ FYM ha ${ }^{-1}, \mathrm{~T}_{10^{-}}$Foliar sprays of $0.5 \% \mathrm{ZnSO}_{4}$ (twice), $\mathrm{T}_{11}$ - Foliar sprays of $1 \% \mathrm{FeSO}_{4}$ (twice at 30 and 45 DAS) and $\mathrm{T}_{12}$ - Combined foliar sprays $\left(0.5 \% \mathrm{ZnSO}_{4}+1 \% \mathrm{FeSO}_{4}\right.$; twice). Zinc and iron were applied by $\mathrm{ZnSO}_{4} \cdot 7 \mathrm{H}_{2} \mathrm{O}$ and $\mathrm{FeSO}_{4} .7 \mathrm{H}_{2} \mathrm{O}$, respectively at the time of sowing of pearl millet and mustard. Foliar sprays of $\mathrm{Zn}$ and $\mathrm{Fe}$ were applied through inorganic salt of $\mathrm{Zn}$ and $\mathrm{Fe}\left(\mathrm{ZnSO}_{4} .7 \mathrm{H}_{2} \mathrm{O}\right.$ and $\mathrm{FeSO}_{4} .7 \mathrm{H}_{2} \mathrm{O}$ ) in both the crops at 30 and 45 days after sowing.

\section{Plant analysis}

\section{Zinc and iron content}

For the determination of ferrous-iron $\left(\mathrm{Fe}^{2+}\right)$ at 50 days after sowing (DAS) plant samples were transported immediately to the laboratory in closed polythene bags and washed copiously with running tap water, followed by $0.1 N$ hydrochloric acid $(\mathrm{HCl})$ and distilled water. The samples were freed-off the sticking water drops by placing them between sheets of clean blotting papers. They were cut into small pieces of approximately 1-2 mm, with the help of stainless steel scissors. The $\mathrm{Fe}^{2+}$ concentration in fresh plant samples was determined by the ortho- phenanthroline method as developed by Katyal and Sharma (1980). In order to remove discrepancies arising due to varying moisture contents of plant samples, the duplicate fresh chopped plant samples were dried to a constant weight at $50-60^{\circ} \mathrm{C}$ in an oven and moisture content was computed. Ferrous-iron concentration in the plant was expressed on dry weight basis. The crop was harvested at maturity and grain and straw samples per plot were collected.

The samples were rinsed thoroughly with 0.1 $N \mathrm{HCl}$ (AR) and then with the deionised water in order to eliminate the contamination of the foliar fertilizer. Plant samples were dried in hot air oven at $60-70^{\circ} \mathrm{C}$, after attaining constant weight, plant samples were ground with a stainless steel sample grinder. The ground samples of the grain and straw were stored in sealed plastic bags at room temperature until they were analyzed. Total plant $\mathrm{Zn}$ and $\mathrm{Fe}$ were digested in di-acid [nitric acid $\left(\mathrm{HNO}_{3}\right)$ : perchloric acid $\left(\mathrm{HClO}_{4}\right)$ :: 9:4] mixture (Jackson, 1973) and determined with the help of Flame Atomic Absorption Spectroscopy (FAAS).

\section{Total chlorophyll content}

Chlorophyll content was estimated according to the method of Hiscox and Israelstam (1979) using dimethyl sulfoxide (DMSO). Fully expanded leaf from plant was detached and weighed $200 \mathrm{mg}$ then kept into a test tube containing $5 \mathrm{ml}$ of DMSO. The test tube was then placed into oven at $60^{\circ} \mathrm{C}$ for about $4 \mathrm{~h}$ to facilitate the extraction of pigment. After 2 hours and attaining the room temperature, the absorption was read at 645 and $665 \mathrm{~nm}$ on spectrophotometer. The DMSO was used as blank. Calculations for different pigments were made according to Wellburn (1994). 
Chl 'a' $(\mu \mathrm{g} / \mathrm{ml})$ - $12.19 \mathrm{~A}_{665}-3.45 \mathrm{~A}_{645}$

Chl 'b' $(\mu \mathrm{g} / \mathrm{ml})$ - $21.99 \mathrm{~A}_{645}-3.32 \mathrm{~A}_{665}$

Total chlorophyll - Chl 'a' + Chl 'b'

Quantity of all these pigments was calculated in $\mathrm{mg} \mathrm{g}^{-1}$ tissue dry weight.

\section{Proline content}

Proline content was estimated by using the method of Bates et al., (1973). The $300 \mathrm{mg}$ of leaves was homogenized in $5 \mathrm{ml}$ of 3 per cent sulphosalicylic acid and then centrifuged at $5000 \mathrm{rpm}$ for 15 minutes and supernatant was taken. Two $\mathrm{ml}$ of supernatant was taken and $2.0 \mathrm{ml}$ reagent acid ninhydrin $+2.0 \mathrm{ml}$ acetic acid was added. This mixture was then kept in boiling water bath for $1 \mathrm{~h}$ at $100^{\circ} \mathrm{C}$ and thereafter, reaction was terminated by keeping tubes in ice-bath. Then $4.0 \mathrm{ml}$ of toluene was added. After vigorous shaking, the upper organic phase was taken after attainment of room temperature and absorbance was recorded at $520 \mathrm{~nm}$ by using toluene as blank. A standard curve was prepared by using graded concentration of proline in $3 \%$ sulphosalicylic acid. The proline content was expressed as $\mu \mathrm{g} \mathrm{g}^{-1}$ dry weight.

\section{Statistical analysis}

Statistical analysis was done in the randomized block design with three replications as per method given by Snedecor and Cochran, 1967. The mean values of treatments were considered for comparison using the critical difference at the $5 \%$ level of significance.

\section{Results and Discussion}

\section{Effect of $\mathrm{Zn}$ and Fe on yield}

The results indicated that with combined application of $5 \mathrm{~kg} \mathrm{Zn}+10 \mathrm{~kg} \mathrm{Fe}+10 \mathrm{t}$ FYM $\mathrm{ha}^{-1}$ pearl millet grain yield (36.6 $\mathrm{q} \mathrm{ha}^{-1}$ ) and mustard seed yield $\left(22.7 \mathrm{q} \mathrm{ha}^{-1}\right)$ were $57.1 \%$ and $42.8 \%$ higher over control. However, yield improvement was only 35.6 and $20.7 \%$ higher over control in pearl millet and mustard, respectively, with the application of $5 \mathrm{~kg} \mathrm{Zn}+10 \mathrm{~kg} \mathrm{Fe} \mathrm{ha}^{-1}$ without FYM. Alone soil application of $7.5 \mathrm{~kg} \mathrm{Zn} \mathrm{ha}^{-1}$ and $12.5 \mathrm{~kg}$ $\mathrm{Fe} \mathrm{ha}^{-1}$ also significantly increased yields of pearl millet and mustard than control. Among the foliar applications, spray of $0.5 \% \mathrm{ZnSO}_{4}$ $+1 \% \mathrm{FeSO}_{4}$ twice was equally effective in increasing the yields of pearl millet and mustard similar to that obtained with the soil application of $5 \mathrm{~kg} \mathrm{Zn} \mathrm{ha}{ }^{-1}$ and $7.5 \mathrm{~kg} \mathrm{Fe} \mathrm{ha}^{-1}$ alone (Table 2).

The direct effect of FYM in pearl millet and its residual effect in mustard were found useful in getting higher yield of crops, which might be due to the favorable effect of FYM on physical, chemical and biological properties in increasing the availability of nutrients in the soil solution. Comparatively less improvement in grain yield of pearl millet was recorded in alone application of $5 \mathrm{~kg} \mathrm{Zn}$ and $7.5 \mathrm{~kg} \mathrm{Fe}$ than combined application treatment $\mathrm{T}_{8}\left(5 \mathrm{~kg} \mathrm{Zn}+7.5 \mathrm{~kg} \mathrm{Fe} \mathrm{ha}^{-1}\right)$ and it was found to decrease by $18.8 \%$ and $22.9 \%$, respectively. Similarly, in case of mustard, the seed yield decreased by 15.0 and $11.6 \%$ in alone application of $5 \mathrm{~kg} \mathrm{Zn} \mathrm{ha}{ }^{-1}$ and $7.5 \mathrm{~kg} \mathrm{Fe}$ $\mathrm{ha}^{-1}$ as compared to combined application ( 5 $\mathrm{kg} \mathrm{Zn}+7.5 \mathrm{~kg} \mathrm{Fe} \mathrm{ha}^{-1}$ ), respectively. This might be due to the favorable synergistic effect of combined application of $\mathrm{Zn}$ and $\mathrm{Fe}$ in the soils which enhanced the better translocation of nutrients by developing good root growth. Subsequently, the treatment $\mathrm{T}_{9}(5$ $\mathrm{kg} \mathrm{Zn+7.5} \mathrm{kg} \mathrm{Fe} \mathrm{+} 10 \mathrm{t} \mathrm{FYM} \mathrm{ha}^{-1}$ ) receiving combined application of $\mathrm{Zn}$ and Fe along with FYM in pearl millet and FYM residual effect in mustard increased the yield of both crops significantly. It could be attributed due to the favorable effect of organic manures in soils, decreasing EC and maintaining the higher amounts of available micronutrients in salt 
affected soils (Kumar et al., 2012). Also, combined foliar application of $\mathrm{Zn}$ and Fe was better than foliar application/sprays of an individual nutrient. Straw yield of both crops followed the same trend as that of grain yield. The response of $\mathrm{Zn}$ and Fe application was higher for yield in pearl millet than mustard. The different response of $\mathrm{Zn}$ and $\mathrm{Fe}$ application to pearl millet and mustard in terms of yield may be related to inherent characteristics of crop to perform under salt affected soils.

The superiority of foliar application of Fe over soil application has earlier been reported by many researchers (Pal et al., 2008; Zhang et al., 2009; Gomez-Galera et al., 2010). Iron is easily translocated acropetally and retranslocated basipetally after foliar application as long as $\mathrm{Fe}$ does not get immobilized. However, Fe (II) salts rapidly oxidize upon exposure to ambient air after soil application (Fernandez and Ebert, 2005). Relative ineffectiveness of soil application of $\mathrm{Fe}$ through inorganic source can be attributed to quick conversion of $\mathrm{Fe}^{2+}$ to $\mathrm{Fe}^{3+}$ under field conditions with high $\mathrm{pH}$ rendering its unavailability to plants (Sarkar et al., 2008).

\section{Effect on physiological parameters}

Chlorophyll and proline content were measured in both the crops. In pearl millet, alone soil application of $\mathrm{Zn}$ through fertilizer significantly $\quad(p=0.05)$ improved total chlorophyll content from 5.07 to $5.16,6.17$ and $6.65 \mu \mathrm{g} / \mathrm{g}$ in the treatment $\mathrm{T}_{2}, \mathrm{~T}_{3}$ and $\mathrm{T}_{4}$, respectively. In similar way, alone soil application of $\mathrm{Fe}$ fertilizer improved the chlorophyll content from 5.07 to $5.63,5.94$ and $7.19 \mu \mathrm{g} / \mathrm{g}$ in response to treatments of $\mathrm{T}_{5}$, $\mathrm{T}_{6}$ and $\mathrm{T}_{7} \mathrm{~kg} \mathrm{Fe} \mathrm{ha}^{-1}$, respectively. Combined soil application of $5 \mathrm{~kg} \mathrm{Zn}+10 \mathrm{~kg} \mathrm{Fe} \mathrm{ha}^{-1}\left(\mathrm{~T}_{8}\right)$ increased chlorophyll content by $48.5 \%$ over control; whereas, same treatment with $10 \mathrm{t}$ FYM ha ${ }^{-1}\left(\mathrm{~T}_{9}\right)$ increased chlorophyll content
92.9\% than control (Table 3). Treatment $\mathrm{T}_{12}$ receiving combined foliar application of $0.5 \%$ $\mathrm{ZnSO}_{4}+1 \% \quad \mathrm{FeSO}_{4}$ had significantly higher chlorophyll content than control in pearl millet. The proline content in pearl millet was also affected by the external application of $\mathrm{Zn}$ and $\mathrm{Fe}$ and its combination (Table 3). Increasing the levels of $\mathrm{Zn}$ from control to highest level of $\mathrm{Zn}\left(7.5 \mathrm{~kg} \mathrm{Zn} \mathrm{ha}{ }^{-1}\right)$ reduced the proline content from 14.43 to $14.11 \mu \mathrm{g} / \mathrm{g}$. Proline content in pearl millet decreased (14.95 to $14.09 \mu \mathrm{g} / \mathrm{g}$ ) in response to increased levels of soil applied Fe (7.5 to $12.5 \mathrm{~kg} \mathrm{ha}^{-1}$ ). Among the treatments, combined application of $5 \mathrm{~kg} \mathrm{Zn}+10 \mathrm{~kg} \mathrm{Fe}+10 \mathrm{t} \mathrm{FYM} \mathrm{ha}^{-1}\left(\mathrm{~T}_{9}\right)$ reduced proline content by $10.95 \%$ than control. Foliar application treatments $\left(\mathrm{T}_{10}, \mathrm{~T}_{11}\right.$ and $\mathrm{T}_{12}$ ) of $\mathrm{Zn}$ and $\mathrm{Fe}$ did not significantly affect proline content in pearl millet.

The chlorophyll and proline content also measured in mustard crop with respect to $\mathrm{Zn}$, $\mathrm{Fe}$ and combined application (Table 3). Similar patterns of $\mathrm{Zn}$ application effect on mustard was observed as that in pearl millet and found that increasing the level of $\mathrm{Zn}$ (5 to $7.5 \mathrm{~kg} \mathrm{ha}^{-1}$ ) enhanced the chlorophyll content from 2.76 , to $2.89 \mu \mathrm{g} / \mathrm{g}$. Soil application of Fe also enhanced chlorophyll content from 2.48 to 2.70 , and 2.90 in $7.5,10$ and $12.5 \mathrm{~kg} \mathrm{Fe} \mathrm{ha}$ 1 , respectively.

Highest chlorophyll content was measured in the combined application of $5 \mathrm{~kg} \mathrm{Zn}+10 \mathrm{~kg} \mathrm{Fe}$ +10 t FYM $(3.48 \mu \mathrm{g} / \mathrm{g})$ which was $41.1 \%$ higher than control. The combined spray application of $\mathrm{Zn}$ and $\mathrm{Fe}$ significantly increased the chlorophyll content by $10.1 \%$ over control in mustard. In general, proline content in mustard leaves decreased with application of $\mathrm{Zn}+\mathrm{Fe}$ either through soil or foliar sprays individually or in combination. However, marked decreased in proline content (30-50\%) was recorded with combined application of $5 \mathrm{~kg} \mathrm{Zn+10} \mathrm{kg} \mathrm{Fe} \mathrm{either} \mathrm{with}$ FYM $(6.51 \mu \mathrm{g} / \mathrm{g})$ or without FYM $(9.18 \mu \mathrm{g} / \mathrm{g})$. 
Table.1 Some selected physico-chemical properties of experimental soil and farm yard manure

\begin{tabular}{|l|c|}
\hline Parameter & Value \\
\hline Soil Properties & \\
\hline $\mathrm{pH}_{\mathrm{S}}(\mathbf{1 : 2})$ & 8.43 \\
\hline $\mathrm{EC}_{\mathrm{e}}\left(\mathrm{dS} \mathrm{m} \mathrm{m}^{-1}\right)$ & 10.71 \\
\hline Organic carbon (\%) & 0.42 \\
\hline DTPA extractable Zn $\left(\mathrm{mg} \mathrm{kg}^{-1}\right)$ & 0.65 \\
\hline Total Zn (aqua regia extractable, $\left.\mathrm{mg} \mathrm{kg}^{-1}\right)$ & 39 \\
\hline DTPA extractable Fe (mg kg-1) & 4.43 \\
\hline Total Fe (aqua regia extractable, \%) & 1.13 \\
\hline FYM (Farm Yard Manure) & \\
\hline Moisture content $(\%)$ & 49 \\
\hline Total Zn $\left(\mathrm{mg} \mathrm{kg}^{-1}\right)$ & 60 \\
\hline Total Fe (mg kg-1) & 200 \\
\hline Total Cu (mg kg-1) & 22 \\
\hline Total $\mathrm{Mn}\left(\mathrm{mg} \mathrm{kg}^{-1}\right)$ & 60 \\
\hline
\end{tabular}

Table.2 Effect on zinc and iron application methods on yield of pearl millet and Mustard (pooled of 4 years)

\begin{tabular}{|c|}
\hline Treatment \\
\hline $\mathrm{T}_{1}$ - Control \\
\hline $\mathrm{T}_{2^{-}} 5 \mathrm{~kg} \mathrm{Zn} \mathrm{ha}$ \\
\hline$T_{3^{-}} 6.25 \mathrm{~kg} \mathrm{Zn} \mathrm{ha}^{-1}$ \\
\hline $\mathrm{T}_{4^{-}} 7.5 \mathrm{~kg} \mathrm{Zn} \mathrm{ha}^{-1}$ \\
\hline$T_{5}-7.5 \mathrm{~kg} \mathrm{Fe} \mathrm{ha}^{-1}$ \\
\hline $\mathrm{T}_{6^{-}} 10 \mathrm{~kg} \mathrm{Fe} \mathrm{ha}{ }^{-1}$ \\
\hline $\mathrm{T}_{7}=12.5 \mathrm{~kg} \mathrm{Fe} \mathrm{ha}^{-1}$ \\
\hline $\mathrm{T}_{8^{-}} 5 \mathrm{~kg} \mathrm{Zn+10} \mathrm{kg} \mathrm{Fe} \mathrm{ha}{ }^{-1}$ \\
\hline $\mathrm{T}_{9}-\mathrm{T}_{8}+10 \mathrm{t}_{\mathrm{FYM}} \mathrm{ha}^{-1}$ \\
\hline $\mathrm{T}_{10^{-}} \mathbf{0 . 5 \%} \mathrm{ZnSO}_{4}$ sprays twice \\
\hline $\mathrm{T}_{11}-1.0 \% \mathrm{FeSO}_{4}$ sprays twice \\
\hline$T_{12^{-}}$Combined sprays $\left(T_{10^{-}}+T_{11}\right)$ \\
\hline $\operatorname{LSD}(P=0.05)$ \\
\hline
\end{tabular}

\begin{tabular}{|c|c|c|c|c|}
\hline \multicolumn{2}{|c|}{ Pearl millet } & \multicolumn{2}{|c|}{ Mustard } \\
\hline Grain & $\begin{array}{c}\text { Stover } \\
\left(\mathrm{q} \mathrm{ha}^{-1}\right)\end{array}$ & \multicolumn{2}{|c|}{ Seed } & Stover \\
\hline 23.3 & 53.9 & 15.9 & 55.3 \\
\hline 26.6 & 62.2 & 16.7 & 60.6 \\
\hline 28.5 & 71.7 & 18.2 & 66.4 \\
\hline 30.7 & 77.6 & 19.4 & 71.6 \\
\hline 25.7 & 64.2 & 17.2 & 60.0 \\
\hline 27.6 & 69.9 & 18.0 & 62.5 \\
\hline 29.2 & 75.5 & 18.5 & 70.7 \\
\hline 31.6 & 76.5 & 19.2 & 79.4 \\
\hline 36.6 & 91.0 & 22.7 & 85.4 \\
\hline 24.1 & 58.6 & 16.6 & 59.7 \\
\hline 27.0 & 64.5 & 17.0 & 60.7 \\
\hline 28.1 & 67.7 & 17.3 & 62.2 \\
\hline 5.8 & 9.6 & 2.3 & 6.3 \\
\hline
\end{tabular}


Table.3 Effect of zinc and iron application rate on total chlorophyll and Proline content (pooled of 4 years)

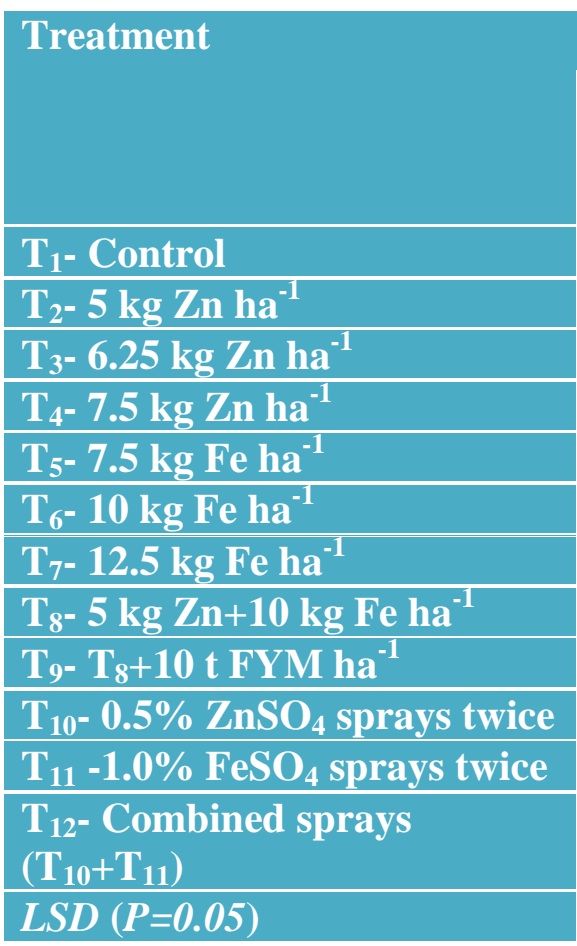

\begin{tabular}{|c|c|c|c|}
\hline \multicolumn{2}{|c|}{ Pearlmillet } & \multicolumn{2}{c|}{ Mustard } \\
\hline $\begin{array}{c}\text { Total Chlorophyll } \\
\left(\mu \mathrm{g} \mathrm{ml}^{-1}\right)\end{array}$ & $\begin{array}{c}\text { Proline } \\
\left(\mu \mathrm{g} \mathrm{g}^{-1}\right)\end{array}$ & $\begin{array}{c}\text { Total } \\
\text { Chlorophyll } \\
\left(\mu \mathrm{g} \mathrm{ml}^{-1}\right)\end{array}$ & $\begin{array}{c}\text { Proline } \\
\left(\mu \mathrm{g} \mathrm{g}^{-1}\right)\end{array}$ \\
\hline 5.07 & 14.43 & 2.48 & 13.14 \\
\hline 5.16 & 13.75 & 2.76 & 13.54 \\
\hline 6.17 & 15.01 & 2.95 & 12.00 \\
\hline 6.65 & 14.11 & 2.89 & 11.58 \\
\hline 5.63 & 14.95 & 2.70 & 13.54 \\
\hline 5.94 & 14.51 & 2.90 & 11.19 \\
\hline 7.19 & 14.09 & 2.55 & 13.25 \\
\hline 7.53 & 14.85 & 2.88 & 9.18 \\
\hline 9.78 & 12.85 & 3.48 & 6.51 \\
\hline 3.92 & 13.80 & 1.91 & 12.84 \\
\hline 4.28 & 14.22 & 2.18 & 12.10 \\
\hline 5.16 & 14.32 & 2.73 & 12.08 \\
\hline 0.41 & & & 0.23 \\
\hline
\end{tabular}

Table.4 Effect of $\mathrm{Zn}$ and $\mathrm{Fe}$ application on $\mathrm{Fe}^{2+}$ and total iron and zinc content in pearl millet and mustard at 50 DAS (pooled of 4 years)

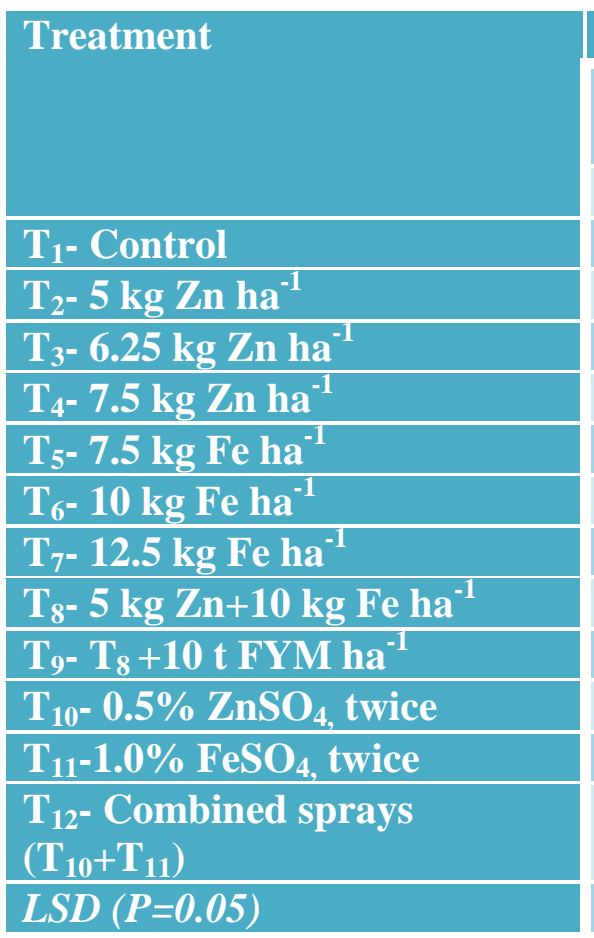

\begin{tabular}{|c|c|c|c|c|c|}
\hline \multicolumn{3}{|c|}{ Pearl millet } & \multicolumn{3}{c|}{ Mustard } \\
\hline $\mathrm{Fe}^{2+}$ & Total Fe & $\begin{array}{c}\text { Total } \\
\mathrm{Zn}\end{array}$ & $\mathrm{Fe}^{2+}$ & $\begin{array}{c}\text { Total } \\
\mathrm{Fe}\end{array}$ & $\begin{array}{c}\text { Total } \\
\mathrm{Zn}\end{array}$ \\
\hline \multicolumn{3}{|c|}{$\left(\mathrm{mg} \mathrm{kg}^{-1}\right)$} & & \multicolumn{3}{|c|}{$\left(\mathrm{mg} \mathrm{kg}^{-1}\right)$} \\
\hline 10.9 & 40.1 & 32.1 & 18.5 & 53.4 & 49.4 \\
\hline 11.9 & 40.4 & 43.8 & 18.9 & 53.9 & 53.7 \\
\hline 12.5 & 40.2 & 49.5 & 19.0 & 54.2 & 54.2 \\
\hline 12.9 & 40.6 & 53.5 & 19.5 & 54.9 & 56.5 \\
\hline 13.2 & 42.9 & 37.7 & 20.2 & 56.2 & 51.0 \\
\hline 13.6 & 44.8 & 39.4 & 20.6 & 58.4 & 52.5 \\
\hline 13.7 & 46.7 & 40.8 & 20.9 & 59.5 & 52.8 \\
\hline 14.6 & 46.0 & 47.6 & 21.4 & 60.4 & 56.4 \\
\hline 15.1 & 45.3 & 51.7 & 23.1 & 63.1 & 59.9 \\
\hline 11.7 & 41.4 & 40.3 & 18.8 & 53.8 & 53.0 \\
\hline 13.2 & 43.0 & 37.1 & 20.1 & 56.0 & 50.9 \\
\hline 13.3 & 45.5 & 42.1 & 20.8 & 57.8 & 54.1 \\
\hline 2.39 & 4.89 & 8.61 & 2.21 & 4.22 & 5.54 \\
\hline
\end{tabular}


Both pearl millet and mustard are the most preferred crops in the northern belt of Punjab, Haryana and Rajasthan. The application of $\mathrm{Zn}$ in saline and alkaline soils improved the physiological parameters of the wheat (Ebrahim and Aly, 2004). Singh et al., (2013) reported that application of $\mathrm{Zn}$ fertilizers in saline soil improved the water content, transpiration rate, protein, chlorophyll content, carbohydrate and starch content in crops. The results of the present study also proved that plant physiological parameters improved by the addition of $\mathrm{Zn}$ and $\mathrm{Fe}$. Application of FYM produced various types of organic acids, which lower down the soil $\mathrm{pH}$ and enhance the availability of $\mathrm{Fe}$ and $\mathrm{Zn}$ in soil. It also left the priming effect on plant nutrients and mobilize the native immobile nutrients in soil. The FYM improved the soil physical, chemical and biological properties and enhance the plant uptake pattern and nutrient mineralization kinetics in soil. Increasing the $\mathrm{Zn}$ concentration in plant enhanced the nucleic acid metabolism and promotes the synthesis of the photosynthesis sink capacity of plants (Cakmak and Kutman, 2018). Rhizospheric manipulation of micronutrients enhanced the crop uptake dynamics and improves the crop yield (Meena et al., 2006; Dotaniya et al., 2016). Proline is a physiological parameter and produced under the stress conditions. Application of $\mathrm{Zn}$ and $\mathrm{Fe}$ reduced the proline content in linseed (Ghildiyal et al., 1986). Similar types of findings were reported in various crops, i.e. barley (Abou Hossein et al., 2002), tomato (Alpaslan et al., 1999) and wheat (Cakmak and Kutman, 2018).

\section{Effect on concentration of $\mathrm{Zn}$ and $\mathrm{Fe}$}

Total Fe content in whole plant of pearl millet was significantly higher in treatment $\mathrm{T}_{7}$ (46.7 $\mathrm{mg} \mathrm{kg}^{-1}$ ) as compared to control (40.1 $\mathrm{mg} \mathrm{kg}^{-}$ ${ }^{1}$ ); whereas, in case of mustard highest total $\mathrm{Fe}$ content was observed under combined soil application of $5 \mathrm{~kg} \mathrm{Zn+10} \mathrm{kg} \mathrm{Fe}+10 \mathrm{t} \mathrm{FYM}$ $\mathrm{ha}^{-1}$ (63.1 mg kg-1) than control (Table 4). Mustard is probably better extractor of soil $\mathrm{Fe}$ from the reserve pools. The lowest total $\mathrm{Fe}$ in straw of experimental crops under control is due to its inherently poor $\mathrm{Fe}$ supplying capacity related to low DTPA-extractable Fe and high $\mathrm{CaCO}_{3}$ content (Meena et al., 2013, Meena et al., 2017) of alkaline soils. Among foliar application, highest $\mathrm{Fe}$ content in straw of pearl millet and mustard was observed under combined foliar spray of $\mathrm{Zn}$ and $\mathrm{Fe}$ followed by alone application of $1 \% \mathrm{FeSO}_{4}$.

Highest $\mathrm{Fe}^{2+}$ content in fresh leaves of pearl millet (15.1 mg kg-1 (23.1 $\mathrm{mg} \mathrm{kg}^{-1}$; dry wt.),) was estimated in treatment $\mathrm{T}_{9}(5 \mathrm{~kg} \mathrm{Zn+10} \mathrm{kg} \mathrm{Fe}+10 \mathrm{t} F Y M$ $\mathrm{ha}^{-1}$ ) which was significantly higher than control treatment at 50 days after sowing of crops. Such variability in Fe content between these two crops is attributed to the inherent genetic differences in ability of the crop to mine Fe from the soil pool (Pal et al., 2008; Meena et al., 2016). On an average, $\mathrm{Fe}$ content in shoot of crop plants was highest in combined soil application of $\mathrm{Zn}$ and $\mathrm{Fe}$ with FYM, followed by straight soil application, combined foliar application of $\mathrm{Zn}$ and $\mathrm{Fe}$ (Table 4). Straight or alone soil and two foliar application of $\mathrm{Fe}$ were equally effective in maintaining the $\mathrm{Fe}^{2+}$ content in plants.

Saline and alkaline soils are having potential to produce a significant amount of food grain, but having $\mathrm{Fe}$ and $\mathrm{Zn}$ micronutrient limitation due to poor availability. In this experiment, external application of $\mathrm{Zn}, \mathrm{Fe}$ and FYM enhanced grain yield by $57.1 \%$ in pearl millet and $42.8 \%$ in mustard. The other plant parameters (total $\mathrm{Zn}$ and $\mathrm{Fe}^{2+}$, chlorophyll content, etc.) were also improved with the application of $\mathrm{Zn}$ and $\mathrm{Fe}$ and also by the combined application with FYM. Ferrous iron $\left(\mathrm{Fe}^{2+}\right)$ at 50 DAS can be used as an indicator for assessing $\mathrm{Fe}$ deficiency in crops. Such 
findings can be considered for planning and improvement of pearl millet and mustard crop yield in saline and alkaline soils of India for sustainable crop yield for food security.

\section{Acknowledgements}

The authors are grateful to the Head, Division of Soil and Crop Management, ICAR-CSSRI, Karnal for providing the instrumental facilities and first author also grateful to Dr. SK Chaudhari, ADG (SWM), ICAR, New Delhi for helping during formulation of project.

\section{References}

Abou-Hossein, E.A., M.M. Shehata and M.A. El-Sherif (2002). Phosphorus nutrition of barley plant as affected by zinc, manganese and organic matter application to saline soils. Egypt. J. Soil Sci., 42: 331-345.

Achakzai, A.K.K., S.A. Kayani and A. Hanif (2010). Effect of salinity on uptake of micronutrients in sunflower at early vegetative stage. Pak. J. Bot., 42: 129139.

Al-Harbi, A.R. (1995). Growth and nutrient composition of tomato and cucumber seedlings as affected by sodium chloride salinity and supplemented calcium. J. Plant Nutr., 18:1403-1408

Alpaslan, M., A. Inal, A. Gunes, Y. Cikili and H. Ozcan (1999). Effect of zinc treatment on the alleviation of sodium and chloride injury in tomato (Lycopersicon esculentum L.) grown under salinity. Turkish J. Bot., 23: 1-6.

Bates, L.S., R.P. Waldren and I.D. Teare (1973). Rapid determination of free proline for water-stress studies. Plant Soil, 39: 205-207.

Cakmak, I. and U.B. Kutman (2018). Agronomic biofortification of cereals with zinc: a review. Eur. J. Soil Sci., 69: 172-180.

Datta, S.P., B.L. Meena and R.K. Rattan (2013). Development of a computer program for calculating metal ion activity using Baker soil test. J. Indian Soc. Soil Sci., 61: 47-50.

Dotaniya, M.L., S.C. Datta, D.R. Biswas, C.K. Dotaniya, B.L. Meena, S. Rajendiran, K.L. Regar, and Manju Lata (2016). Use of sugarcane industrial byproducts for improving sugarcane productivity and soil health. Int. J. Recycl. Org. Waste Agricult., 5: 185194.

Ebrahim, M.K.H. and M.M. Aly (2004). Physiological response of wheat to foliar application of zinc and inoculation with same bacterial fertilizers. J. Plant Nutr., 27: 1859-1874.

Fernandez, V. and G. Ebert: (2005). Foliar iron fertilization: a critical review. J. Plant Nutr., 28: 2113-2124.

Ghildiyal, M.C., M. Pandey and G.S. Sirohi (1986). Proline content in linseed varieties as influenced by zinc nutrition. Indian J. Plant Physiol., 29: 368-374.

Gomez-Galera, S., E. Rojas, D. Sudhakar, C. Zhu, A.M. Pelacho, T. Capell and P. Christou (2010). Critical evaluation of strategies for mineral fortification of staple food crops. Transgic. Res., 19:165-180.

Hiscox, J. D. and G.F. Israelstam (1979). A method for the extraction of chlorophyll from leaf tissue without maceration. Can. J. Bot., 52: 332-334.

Jackson, M.L. (1973). Soil Chemical Analysis. Prentice Hall of India Pvt. Ltd., New Delhi

Katyal, J.C. and B.D. Sharma (1980). A new technique of plant analysis to resolve iron chlorosis. Plant Soil, 55: 105-119.

Knight, S.L., R.B. Rogers, M.A.L. Smith and L.A. Spomer (1992). Effects of $\mathrm{NaCl}$ salinity on miniature dwarf tomato 
'Micro-Tom': I. Growth analyses and nutrient composition. J. Plant Nutr., 15: 2315-2327.

Kumar, M., N.P.S. Yaduvanshi and Y.V. Singh (2012). Effects of integrated nutrient management on rice yield, nutrient uptake and soil fertility status in reclaimed sodic soils. J. Indian Soc. Soil Sci., 60:132-137.

Lindsay, W.L. and W.A. Norvell (1978). Development of a DTPA soil test for zinc, iron, manganese and copper. Soil Sci. Soc. Am. J., 42: 421-428.

Meena B.L., R. K. Fagodiya, K. Prajapat, M. L. Dotaniya, M. J. Kaledhonkar, P. C. Sharma, R.S. Meena, T. Mitran and S. Kumar (2018). Legume Green Manuring: An Option for Soil Sustainability. In: Meena R. et al., (eds) Legumes for Soil Health and Sustainable Management. Springer, Singapore, pp. 387-408.

Meena, B.L., R.K. Rattan, and S.P. Datta (2013). Efficacy of seed treatment in ameliorating iron deficiency in aerobic rice on a calcareous soil. J. Indian Soc. Soil Sci., 61: 147-152.

Meena, B.L., R.K. Rattan, S.P. Datta (2017). Solubility relationship of iron and Evaluation of its Fertility Status in Degraded Soils. Commun. Soil Sci. Plant Anal., 48: 1059-1067.

Meena, B.L., R.K. Rattan, S.P. Datta, M.C. Meena (2016). Effect of iron application on iron nutrition of aerobic rice grown in different soils. J. Environ. Biol., 37: 1377-1383.

Meena, B.L., R.L. Meena, S.K. Ambast and M. Pandey (2014). Impact Assessment of Agriculture Technological Interventions in tunami Affected South Andaman - A Case Study. Bhartiya Krishi Anushandhan Patrika, 28(3): 141-148.

Meena, M.C., K.P. Patel, and D.D. Rathod (2006). Effect of $\mathrm{Zn}$ and $\mathrm{Fe}$ enriched
FYM on mustard yield and micronutrient availability in loamy sand soil (Typic Haplustept) of Anand. J. Indian Soc. Soil Sci., 54: 495-499.

Pal, S., S.P. Datta, R.K. Rattan and A.K. Singh (2008). Diagnosis and amelioration of iron deficiency under aerobic rice. J. Plant Nutr., 31: 919-940.

Quevauviller, $\mathrm{Ph}$ (1998). Operationally defined extraction procedures for soil and sediment analysis I. Standardization. Trends Anal. Chem., 17: 289-298.

Rahman, S., G.F. Vance and L.C. Munn (1993). Salinity induced effects on the nutrient status of soil, corn leaves and kernels. Comm. Soil. Sci. Plant Anal., 24: 2251-2269.

Raja, R., N. Ravisankar, S.G. Chaudhuri, S.K. Ambast, S. Chand, M. Din, B.L. Meena, T. Subramani, Z. Ahmed (2012). Effect of supplemental irrigation on yield and water productivity of dry season crops in Andaman and Nicobar Islands. Indian J. Agr. Sci., 82: 43-48.

Ray, P., B.L. Meena, C.P. Nath (2014). Management of coastal soils for improving soil quality and productivity. Pop. Kheti, 2:95-99.

Sarkar, R., B. Basavaraj and S. Kar (2008). Iron and calcium availability to groundnut plants as affected by calcium carbonate and water levels in calcareous soil. J. Crop Improv., 21: 209-220.

Sharma, B.D., R. Kumar, B. Singh and M. Sethi (2009). Micronutrients distribution in salt-affected soils of the Punjab in relation to soil properties. Arch. Agron. Soil Sci., 55: 367-377

Shukla, A.K., P.K. Tiwari and C. Prakash (2014). Micronutrients deficiencies visa-vis food and nutritional security of India. Indian J. Fert., 10: 94-112.

Singh, D., P.C. Ram, A. Singh, S.R. Dar and J.P. Srivastava (2013). Alleviation of soil salinity by zinc fertilizer in wheat 
(Triticum aestivum L.). Plant Arch., 13: 311-316.

Singh, Y., T. Singh, U.N. Singh and P.K. Rajput (2010). Effect of nutrient management on yield, quality and economics of irrigated Indian mustard (Brassica juncea). Indian J. Agr. Sci., 80: 691-694.

Snedecor, G.W. and W. Cochran (1967). Statistical Methods. Sixth Edition, Iowa State University Press, Ames, Iowa.

Wellburn, A. R. (1994). The spectral determination of chlorophyll $\mathrm{a}$ and chlorophyll b, as well as total carotenoids, using various solvents with spectrophotometers of different resolution. J Plant Physiol., 144:307313

Zhang, J., M.Y. Wang and L.H. Wu (2009). Can foliar iron-containing solutions be a potential strategy to enrich iron concentration of rice grains (Oryza sativa L.)? Acta Agric. Scand. Sect. B Soil Plant Sci., 59: 389-394.

\section{How to cite this article:}

Meena, B.L., P. Kumar, A. Kumar, R.L. Meena, M.J. Kaledhonkar and Sharma, P.C. 2018. Zinc and Iron Nutrition to Increase the Productivity of Pearl Millet-Mustard Cropping System in Salt Affected Soils. Int.J.Curr.Microbiol.App.Sci. 7(08): 3201-3211. doi: https://doi.org/10.20546/ijcmas.2018.708.343 